\title{
PROFIL PENILAIAN HASIL BELAJAR SISWA BERDASARKAN KURIKULUM 2013
}

\author{
I Wayan Subagia', I G. L. Wiratma² \\ 1,2 Jurusan Pendidikan Kimia, \\ Universitas Pendidikan Ganesha, Indonesia \\ e-mail: aigabus@yahoo.co.id
}

\begin{abstract}
Abstrak
Penelitian ini bertujuan untuk mendeskripsikan profil penilaian hasil belajar siswa berdasarkan implementasi Kurikulum 2013. Penelitian ini merupakan penelitian deskriptif kualitatif dengan pendekatan fenomenologi. Subjek yang dilibatkan dalam penelitian ini adalah 15 orang guru yang terdiri atas guru SD, SMP, dan SMA, masing-masing lima orang. Data yang dibutuhkan untuk penelitian ini dikumpulkan dengan angket, dokumen, dan wawancara. Data yang diperoleh dianalisis secara deskriptif interpretatif. Hasil penelitian ini menunjukkan bahwa deskripsi profil penilaian hasil belajar siswa dilihat dari sembilan aspek penilaian, yaitu: ranah penilaian, pelaku penilaian, jenis alat penilaian, bentuk tes, bentuk nontest, bentuk laporan hasil belajar, skala penilaian, waktu penilaian, dan teknik pengumpulan hasil belajar. Dalam melakukan penilaian hasil belajar, guru mengalami beberapa masalah berkaitan dengan jumlah unsur penilaian, kompleksitas penilaian, pembuatan instrumen penilaian, pelaksanaan penilaian, dan pelaporan hasil penilaian. Berdasarkan temuan tersebut, disarankan agar penilaian hasil belajar siswa disederhanakan dan tetap memenuhi prinsip-prinsip penilaian, seperti komprehensif, objektif, transparan, dan akuntabel.
\end{abstract}

Kata Kunci: penilaian, hasil belajar, dan kurikulum 2013.

\begin{abstract}
This research aimed at describing the profile of students' learning achievement based on the implementation of 2013 Curriculum. This research was a qualitative descriptive research using phenomenological approach. The total subjects of this research were 15 teachers including five elementary school, junior high school, and senior high school, respectively. Questionnaire, document, and interview techniques were used to collect all data. Descriptive interpretive technique was used to analyse all data. The research results revealed that the description of the profiles of students' learning achievement are viewed from nine evaluation aspects, namely: domain of learning - achievement, evaluator, assessment tools, the form of test, the form of non-test, the form of report, the scale used, the period of assessment, and the techniques of assessment. In evaluating students' learning achievement, teacher faces problems related to the number of evaluation elements, the complexity of evaluation, instrument formulation, assessment frequency, and reporting assessment results. Based on this finding, it is suggested that the evaluation of students' learning achievement should be simplified and still fulfilling the principle of assessment, such as comprehensive, objective, transparent, and accountable.
\end{abstract}

Keywords: assessment, learning echievement, and 2013 curriculum. 


\section{PENDAHULUAN}

Mulai tahun 2013 Pemerintah, melalui Kementerian Pendidikan dan Kebudayaan, melakukan inovasi dalam bidang pendidikan berupa penerapan kurikulum baru yang dikenal dengan Kurikulum 2013. Penerapan tersebut tidak luput dari berbagi kontroversi pro dan kontra di kalangan praktisi pendidikan karena berbagai alasan. Salah satunya adalah masalah pengintegrasian mata pelajaran IPA SD ke dalam mata pelajaran bahasa yang dipandang dapat mengurangi kompetensi siswa dalam bidang IPA. Berkaitan dengan isu tersebut, Wamen, Prof. Musliar Kasim, menyatakan bahwa anak SD cukup belajar ilmu dasar, sehingga tidak perlu membawa banyak buku. Dengan penyederhanaan jumlah mata pelajaran, diharapkan anak didik tingkat SD lebih banyak mendapat pendidikan karakter yang baik, logika berpikir dan pendidikan olahraga. Menteri Pendidikan dan Kebudayaan, Mohammad Nuh, menyatakan bahwa walaupun mata pelajaran IPA tidak menjadi mata pelajaran tersendiri pada Kurikulum 2013 bukan berarti pelajaran IPA dihapus, tetapi metode pembelajarannya diubah menjadi metode tematik integratif.

Kehadiran Kurikulum 2013 dimaksudkan sebagai salah salah satu pemecah masalah bangsa yang dirasakan semakin kompleks, yaitu untuk mengatasi pembangunan sumber daya manusia dan daya saing bangsa (human developmen and nation competitiveness). Berdasarkan data hasil penelitian yang dilakukan oleh Trends in International Mathematics and Science Assessment Study (TIMSS) maupun Program for International
Students Assessment (PISA) sejak tahun 1999, menunjukkan bahwa capaian anak-anak Indonesia masih ada dalam urutan bawah atau belum menggembirakan. Diduga bahwa salah satu penyebabnya adalah materi uji yang diberikan tidak masuk dalam kurikulum pendidikan di Indonesia (Permendikbud No. 67/2013).

Saat ini, pemerintah sudah mulai mengimplementasikan Kurikulum 2013 secara terbatas melalui beberapa sekolah percobaan (pilot project) mulai dari tingkat sekolah dasar (SD) sampai dengan tingkat sekolah menengah atas (SMA/SMK). Salah satu masalah serius dalam implementasi Kurikulum 2013 adalah masalah penilaian hasil belajar siswa. Sesuai dengan tuntutan Kurikulum 2013, penilaian hasil belajar siswa diharapkan dilakukan secara komprehensif dengan melibatkan ketiga ranah utama penilaian, yaitu ranah sikap, pengetahuan, dan keterampilan. Penilaian hasil belajar siswa diharapkan mengalami perubahan penekanan sejalan dengan peningkatan jenjang pendidikan. Pada jenjang pendidikan dasar (SD dan SMP), penilaian hasil belajar lebih banyak ditekankan pada dimensi sikap, diikuti dengan dimensi keterampilan, dan pengetahuan. Sementara, pada jenjang pendidikan lanjut (SMA/SMK) penekanan penilaian hasil belajar siswa lebih banyak pada dimensi pengetahuan, diikuti dengan dimensi keterampilan dan dimensi sikap (Permendikbud No. 66/2013). Di samping dalam ranah penilaian, cara pelaporan hasil belajar siswa dalam raport juga mengalami perubahan yang signifikan. Hasil belajar siswa tidak hanya dikomunikasikan dalam bentuk angka-angka prestasi belajar, tetapi 
dalam bentuk deskripsi kemampuan (kompetensi) peserta didik yang diberikan dalam bentuk deskripsi kemampuan dengan kata-kata.

Berdasarkan hasil pengamatan terbatas di sekolah-sekolah yang menjadi pilot project implementasi Kurikulum 2013, ditemukan bahwa para pemangku kepentingan (sekolah/guru) mengalami masalah dalam merumuskan hasil belajar siswa dalam bentuk katakata. Penyebab masalah tersebut dikontribusi oleh berbagai hal, antara lain: kebiasaan lama guru yang mengalkulasi hasil belajar siswa dalam bentuk angka-angka berdasarkan hasil ulangan harian, ulangan tengah semester, dan ulangan akhir semester, serta kekurangan pengetahuan dan pengalaman guru dalam membuat deskripsi kompetensi siswa. Berpijak pada temuan tersebut, dipandang perlu untuk menelusuri lebih jauh tentang profil penilaian hasil belajar siswa berdasarkan Kurikulum 2013 yang dilakukan guru di sekolah-sekolah percobaan dan permasalahan-parmasalahan yang dihadapi guru dalam merumuskan dan melaporkan hasil belajar siswa melalui sebuah penelitian ilmiah. Diharapkan, temuan hasil penelitian ini dapat dijadikan acuan untuk memecahkan masalah-masalah yang dihadapi guru/sekolah dalam memformulasikan penilaian hasil belajar siswa.

Untuk menelusuri hal tersebut, digunakan peraturan pemerintah yang terkait dengan implementasi Kurikulum 2013 sebagai acuan penelitian. Dalam hal ini, peraturan pemerintah yang digunakan adalah Undang-Undang No. 20 Tahun 2003 tentang Sistem Pendidikan Nasional, Permendikbud No. 66 Tahun 2013 tentang Standar
Penilaian Pendiikan, dan Permendikbud No. 67 Tahun 2013 tentang Kerangka Dasar dan Struktur Kurikulum Sekolah Dasar/Madrasah Ibtidaiyah.

Dalam Undang-Undang No. 20/2003, kurikulum didefinisikan sebagai seperangkat rencana dan pengaturan mengenai tujuan, isi, dan bahan pelajaran serta cara yang digunakan sebagai pedoman penyelenggaraan kegiatan pembelajaran untuk mencapai tujuan pendidikan tertentu. Berdasarkan definisi tersebut, Kurikulum 2013 dipandang sebagai pedoman penyelenggaraan kegiatan pembelajaran, khususnya cara penilaian hasil belajar yang ditelusuri dalam penelitian ini.

Kurikulum 2013 dikembangkan dengan penyempurnaan sembilan pola pikir, yaitu: 1) pola pembelajaran dari berpusat pada guru menjadi berpusat pada siswa, 2) pola pembelajaran satu arah menjadi pola pembelajaran interaktif, 3) pola pembelajaran terisolasi menjadi pola pembelajaran jejaring, 4) pola pembelajaran pasif menjadi pola pembelajaran aktif, 5) pola pembelajaran sendiri menjadi pola pembelajaran kelompok, 6) pola pembelajaran dengan menggunakan alat tunggal menjadi pola pembelajaran berbasis alat multimedia, 7) pola pembelajaran berbasis masal menjadi pola pembelajaran berbasis kebutuhan pelanggan, 8) pola pembelajaran ilmu pengetahuan tunggal menjadi pembelajaran ilmu pengetahuan jamak, dan 9) pola pembelajaran pasif menjadi pembelajaran kritis (Permendikbud, No 67/2013).

Berbeda dengan kurikulum sebelumnya (KTSP), Kurikulum 2013 mempunyai karakteristik, tujuan, dan struktur yang berbeda. Karakteristik 
Kurikulum 2013 ada tujuh, yaitu: 1) mengembangkan keseimbangan antara sikap sosial dan spiritual, rasa ingin tahu kreativitas, kerja sama dengan kemampuan intelektual dan psikomotorik; 2) memandang sekolah sebagai bagian dari masyarakat yang memberikan pengalaman belajar secara terencana dengan memanfaatkan sekolah sebagai tempat belajar dan masyarakat sebagai sumber belajar; 3) mengembangkan sikap, pengetahuan dan keterampilan, serta menerapkannya dalam berbagai situasi di sekolah dan di masyarakat; 4) memberi waktu yang leluasa untuk mengembangkan sikap, pengetahuan, dan keterampilan; 5) merumuskan kompetensi sasaran pembelajaran dalam bentuk kompetensi inti kelas yang dirinci lebih lanjut dalam kompetensi dasar mata pelajaran; 6) menjadikan kompetensi inti kelas sebagai unsur pengorganisasi kompetensi dasar yang menekankan proses pembelajaran pada pencapaian komeptensi inti; dan 7) mengembangkan kompetensi dasar dengan prinsip akumulatif, saling memperkuat dan memperkaya antarmatapelajaran dan jenjang pendidikan (Permendikbud, No. 67/2013)

Struktur Kurikulum 2013 terdiri atas Standar Kompetensi Lulusan (SKL), Kompetensi Inti $(\mathrm{KI})$, dan Kompetensi Dasar (KD). Selain SKL, KI, dan KD, dalam Kurikulum 2013, Pemerintah juga menyiapkan silabus mata pelajaran, buku pegangan siswa, dan buku pegangan guru sebagai acuan pelaksanaan pembelajaran. Namun demikian, Rencana Pelaksanaan Pembelajaran (RPP) tetap dipersiapkan oleh guru.
Standar Kompetensi Lulusan (SKL) dinyatakan dalam dimensi sikap, pengetahuan, keterampilan yang secara umum memiliki orientasi sama dan berbeda dalam implementasi sesaui dengan jenjang pendidikan. Misalnya, untuk jenjang pendidikan sekolah dasar (SD), kualifikasi kemampuan yang distandarkan adalah sebagai berikut. 1) Dimensi sikap dengan kualifikasi kemampuan memiliki perilaku yang mencerminkan sikap orang beriman, berakhlak mulia, berilmu, percaya diri, dan bertanggung jawab dalam berinteraksi secara efektif dengan lingkungan sosial dan alam di lingkungan rumah, sekolah, dan tempat bermain. 2) Dimensi pengetahuan dengan kualifikasi kemampuan memiliki pengetahuan faktual dan konseptual berdasarkan rasa ingintahunya tentang ilmu pengetahuan, teknologi, seni, dan budaya dalam wawasan kemanusiaan, kebangsaan, kenegaraan, dan peradaban terkait fenomena dan kejadian di lingkungan rumah, sekolah, dan tempat bermain. 3) Dimensi keterampilan dengan kualifikasi kemampuan memiliki kemampuan pikir dan tindak yang produktif dan kreatif dalam ranah abstrak dan konkret sesuai dengan yang ditugaskan kepadanya. Dimensi-dimensi tersebut, selanjutnya dikembangkan dalam berbagai jenjang kompensi inti (KI).

Kompetensi inti (KI) terdiri atas empat jenis, yaitu: 1) Kompetensi Inti 1 (KI-1) tentang sikap spiritual, 2) Kompetensi Inti 2 (KI-2) tentang sikap sosial, 3) Kompetensi Inti 3 (KI-3) tentang pengetahuan, dan 4) Kompetensi Inti 4 (KI-4) tentang keterampilan. Contoh kompetensi inti untuk tingkat sekolah dasar (SD/MI) kelas I adalah sebagai berikut: $\mathrm{KI}-1$. Menerima dan menjalankan 
ajaran agama yang dianutnya. KI-2. Memiliki perilaku jujur, disiplin, tanggung jawab, santun, peduli, dan percaya diri dalam berinteraksi dengan keluarga, teman, dan guru. KI-3. Memahami pengetahuan faktual dengan cara mengamati (mendengar, melihat, membaca) dan menanyakan berdasarkan rasa ingin tahu tentang dirinya, makhluk ciptaan Tuhan dan kegiatannya, dan benda-benda yang dijumpainya di rumah dan di sekolah. KI4. Menyajikan pengetahuan faktual dalam bahasa yang jelas dan logis, dalam karya yang estetis, dalam gerakan yang mencerminkan anak sehat, dan dalam tindakan yang mencerminkan perilaku anak beriman dan berakhlak mulia.

Kurikulum 2013 merupakan gagasan inovatif untuk merencanakan dan melaksanakan pembelajaran serta menilai hasil belajar secara komprehensif dengan melibatkan tiga ranah penilaian pembelajaran, yaitu penilaian sikap, pengetahuan, dan keterampilan. Pendekatan ilmiah merupakan pendekatan pembelajaran yang menuntut pengelolaan pembelajaran dilakukan melalui proses ilmiah. Proses ilmiah yang dilakukan sesuai dengan tahapan metode ilmiah mampu memberi wahana pengembangan keterampilan ilmiah dan sikap ilmiah yang keduanya merupakan elemen dasar pencapaian tujuan pendidikan nasional, yaitu untuk mengembangkan potensi peserta didik agar menjadi manusia yang beriman dan bertakwa kepada Tuhan Yang Maha Esa, berakhlak mulia, sehat, berilmu, cakap, kreatif, mandiri, dan menjadi warga negara yang demokratis serta bertanggung jawab (Subagia, 2013).
Istilah penilaian dalam bahasa Indonesia dapat bersinonim dengan evaluasi (evaluation) dan kini juga popular istilah asesmen (assessment). Ada banyak definisi penilaian, walaupun berbeda rumusan, pada umumnya menunjuk pada pengertian yang hampir sama. Lynch (1996) mengemukakan bahwa penilaian adalah usaha yang sistematis untuk mengumpulkan informasi untuk membuat pertimbangan dan keputusan. Douglas (2004) yang sengaja memilih istilah Tes mengartikannya sebagai cara pengukuran keterampilan, pengetahuan, atau penampilan seseorang dalam konteks yang sengaja ditentukan. Definisi lain, penilaian diartikan sebagai proses pengumpulan dan pengolahan informasi untuk mengukur pencapaian hasil belajar peserta didik (PP No.19 Th 2005).

Penilaian hasil belajar adalah kegiatan penyetandaran hasil belajar siswa yang dilakukan melalui dua kegiatan pokok, yaitu kegiatan esesmen dan evaluasi. Esesmen dimaknai sebagai kegiatan pengumpulan hasil belajar, sedangkan evaluasi dimaknai sebagai kegiatan penyetandaran atau pengolahan hasil belajar. Hasil belajar adalah kemampuan siswa dalam memenuhi suatu tahapan pencapaian pengalaman belajar dalam satu kompetensi dasar (Kunandar, 2007). Hasil belajar dalam silabus berfungsi sebagai petunjuk tentang perubahan perilaku yang akan dicapai oleh siswa sehubungan dengan kegiatan belajar yang dilakukan, sesuai dengan kompetensi dasar dan materi standar yang dikaji.

Hasil belajar siswa yang diperoleh dari kegiatan pembelajaran di 
sekolah selalu sejalan dengan tujuan yang tercantum pada indikator yang sudah direncanakan oleh guru. Dalam menyusun atau menetapkan indikator, guru mengacu pada taksonomi tujuan pendidikan yang disusun oleh Bloom, yaitu berupa pengetahuan (ranah kognitif), sikap (ranah afektif), dan keterampilan (ranah psikomotor) yang ketiganya dapat dirinci lagi menjadi bermacam-macam kemampuan yang perlu dikembangkan dalam setiap proses pembelajaran (Arikunto, 1999).

Menurut Suprijono (2009), hasil belajar adalah pola-pola perbuatan, nilainilai, pengertian-pengertian, sikap-sikap, apresiasi dan keterampilan. Selanjutnya Supratiknya (2012) mengemukakan bahwa hasil belajar yang menjadi objek penilaian kelas berupa kemampuankemampuan baru yang diperoleh siswa setelah mereka mengikuti proses belajar mengajar tentang mata pelajaran tertentu. Dalam sistem pendidikan nasional rumusan tujuan pendidikan mengacu pada klasifikasi hasil belajar dari Bloom yang secara garis besar yaitu aspek kognitif, aspek afektif dan aspek psikomotor.

Menurut Hamalik (dalam Ekawarna, 2011) mengemukakan bahwa "hasil belajar adalah perubahan tingkah laku pada diri siswa, yang dapat diamati dan diukur dalam bentuk perubahan pengetahuan, sikap dan keterampilan. Hasil belajar itu biasanya dinyatakan dalam bentuk angka, huruf atau katakata baik, sedang, kurang dan sebagainya"."Hasil belajar nyata dari apa yang dapat dilakukannya yang tidak dapat dilakukannya sebelumnya. Maka terjadi perubahan kelakuan yang dapat kita amati dan dapat dibuktikannya dalam perbuatan" (Nasution, 2000).
Jihad (2008) mengemukakan bahwa "hasil belajar merupakan pencapaian bentuk perubahan perilaku yang cenderung menetap dari ranah kognitif, afektif, dan psikomotoris dari proses belajar yang dilakukan dalam waktu tertentu".

Menurut Munadi (2008) faktorfaktor yang memengaruhi proses dan hasil belajar ada dua yaitu faktor internal dan faktor eksternal.Secara lebih luas, penilaian hasil belajar dimaknai sebagai penilaian hasil pendidikan atau penilaian pendidikan. Berdasarkan Permendikbud No. 66 tahun 2013 tentang Standar Penilaian Pendidikan, dinyatakan bahwa hasil penilaian pendidikan perlu distandarisasi. Standar penilian pendidikan didefinisikan sebagai kriteria mngenai mekanisme, prosedur, dan instrumen penilaian hasil belajar peserta didik. Bentuk-bentuk penilaian hasil belajar siswa yang direkomendasikan mencakup: penilaian autentik, penilaian diri, penilaian berbasis portofolio, ulangan, ulangan harian, ulangan tengah semester, ulangan ahkir semester, ujian tingkat kompetensi, ujian mutu tingkat kompetensi, ujian nasional, dan ujian sekolah/madrasah. Selain standar dan bentuk penilaian pendidikan, pelaksanaan penilaian pendidikan juga dilakukan berdasarkan prinsip-prinsip: objektif, terpadu, ekonomis, transparan, akuntabel, dan edukatif.

Penilaian hasil belajar siswa dilakukan dengan berbagai teknik sesuai dengan kompetensi yang hendak dinilai. Penilaian kompetensi sikap dilakukan melalui observasi, penilaian diri, penilaian "teman sejawat" (peer assessment) oleh peserta didik dan jurnal. Penilaian kompetensi pengetahuan dilakukan melalui tes tulis, 
tes lisan, dan penugasan. Penilaian kompetensi keterampilan dilakukan melalui penilaian kinerja berupa kenerja praktik, projek, dan penilaian portofolio.

Pendekatan penilaian hasil belajar menekankan pada pengukuran tingkat berpikir siswa dari yang rendah sampai dengan yang tinggi; menggunakan pertanyaan mendalam, bukan sekadar hafalan; mengukur proses kerja siswa, bukan hanya hasil kerja siswa; dan menggunakan portofolio pembelajaran siswa. Tingkat berpikir siswa dikembangkan mulai dari tingkat berpikir mengingat, memahami, menerapkan, menganalisis, menilai, dan berkreasi. Pertanyaan dalam pembelajaran ditekankan pada jenis pertanyaan bagaimana dan mengapa yang bersifat rasional, bukan pada pertanyaan apa, dimana, siapa, dan kapan yang bersifat faktual.

Laporan penilaian hasil belajar siswa kepada orang tua, di samping dinyatakan dengan angka dan huruf, juga dinyatakan dalam kata-kata yang menggambarkan kemampuan peserta didik sesuai dengan kompetensi yang dimiliki. Pengolahan hasil-hasil penialain hasil belajar menjadi laporan hasil belajar kepada orang tua (raport siswa), dinyatakan dalam bentuk angka, huruf, dan predikat serta deskripsi untuk capaian kompetensi. Angka yang digunakan adalah dalam skala empat, huruf $A-D$ dan predikat kurang, cukup, baik, dan sangat baik. Hubungan antara interval angka dan huruf serta predikat dapat dilihat pada tabel 1 .

Tabel 1. Pedoman Konversi Nilai

\begin{tabular}{cccc}
\hline Interval Nilai & & Nilai & Preddikat \\
\hline & $3,67-4,00$ & A & Sangat \\
$3,34-3,66$ & A- & Baik \\
$3,01-3,33$ & B+ & Baik \\
$2,67-3,00$ & B & \\
$2,34-2,66$ & B- & \\
$2,01-2,33$ & C+ & Cukup \\
$1,67-2,00$ & C & \\
$1,34-1,66$ & C- & \\
$1,01-1,33$ & D+ & Kurang \\
1.00 & D & \\
\hline
\end{tabular}

Dalam deskripsi pencapaian kompetensi diuraikan kompetensi yang sudah dicapai dan yang perlu ditingkatkan.

Berdasarkan uraian di atas, masalah yang hendak dipecahkan dalam penelitian ini adalah tentang profil penilaian hasil belajar siswa berdasarkan Kurikulum 2013 yang dilakukan oleh guru dan masalah-masalah yang dihadapi guru dalam merumuskan penilaian hasil belajar siswa.

\section{METODE}

Penelitian ini merupakan penelitian deskriptif kualitatif (Sugiyono, 2006). Tujuan dari penelitian ini adalah untuk mendeskripsikan profil penilaian hasil belajar siswa berdasarkan Kurikulum 2013 yang dilaksanakan oleh guru-guru 
di sekolah percobaan. Penelitian ini dilaksanakan di Kota Singaraja, Kabupaten Buleleng, Provinsi Bali pada tahun pelajaran 2014 - 2015. Guru-guru yang dilibatkan dalam penelitian ini berjumlah 15 orang yang terdiri atas guru SDN 3 Banjar Jawa, SMPN 1 Singaraja, dan SMAN 1 Singaraja masing-masing lima orang.

Data yang diperlukan dalam peneilitian ini dikumpulkan melalui angket, dokumentasi, dan wawancara. Angket digunakan untuk mengeksplorasi proses penilain hasil belajar siswa yang dilakukan guru dengan 16 pertanyaan pokok, yaitu: 1) ranah/domein penilaian, 2) pelaku penilaian, 3) jenis penilaian, 4) bentuk tes, 5) bentuk nontes, 6) bentuk pelaporan hasil belajar, 7) skala penilaian, 8) waktu penilaian, 9) teknik pengumpulan hasil belajar, 10) perubahan skor menjadi nilai, 11) penetapan nilai dalam bentuk angka, 12) pengategorian hasil pengamatan, 13) pengategorian hasil wawancara, 14) pengategorian hasil produk, 15) penggunaan nilai hasil remidi, dan 16) penetapan nilai raport. Dokumentasi yang dilakukan adalah dokumentasi laporan hasil belajar siswa (raport) yang dibagikan kepada siswa. Wawancara dilakukan untuk menggali permasalahanpermasalahan yang dihadapi guru dalam proses penilaian hasil belajar siswa.

Seluruh data yang diperoleh dianalisis secara deskriptif interpretatif dengan teknik triangulasi sumber informasi dan triangulasi metode melalui tahapan pendeskripsian data mentah, pengecekan kridibilas data, penyajian data secara bersama-sama, dan interpretasi data (Sugiyono, 2006). Analisis data dilakukan secara bertahap sesuai dengan tahapan pengumpulan data. Secara keseluruhan, analisis data dilakukan sebagai berikut: 1) Analisis data yang diperoleh dari hasil penyebaran angket dilakukan dengan mentabulasi tanggapan yang diberikan oleh responden, mendeskripsikan, dan menginterpretasi data yang diperoleh. 2) Analisis data hasil dokumen dilakukan dengan membandingkan isi dokumen dengan jawaban yang diberikan dalam angket. 3) Analisis data yang diperoleh dari wawancara dilakukan dengan mendeskripsikan informasi yang diberikan oleh para informan. Kredibitas informasi yang diperoleh ditingkatkan dengan metode triangulasi sumber informasi.

\section{HASIL DAN PEMBAHASAN}

Termuan hasil penelitian ini dikelompokkan menjadi dua, yaitu profil penilaian hasil belajar siswa berdasarkan Kurikulum 2013 yang dilakukan oleh para guru dan permasalahan-permasalahan yang ditemukan guru dalam pelaksanaan penilaian hasil belajar siswa.

\section{Profil Penilaian Hasil Belajar Siswa}

Profil penilaian hasil belajar siswa digambarkan melalui sembilan aspek, yaitu: 1) ranah/domein penilaian, 2) pelaku penilaian, 3) jenis alat penilaian, 4) bentuk tes, 5) bentuk nontes, 6) bentuk pelaporan hasil belajar, 7) skala penilaian, 8) waktu penilaian, 9) teknik pengumpulan hasil belajar.

1) Ranah/domain penilaian

Ranah atau domain penilaian yang digunakan dalam penilaian hasil belajar siswa meliputi ranah sikap, pengetahuan, dan keterampilan. Ranah sikap yang dinilai adalah sikap spiritual dan sikap sosial. Instrumen yang digunakan untuk penilaian sikap 
dikembangkan oleh tiap-tiap guru. Indikator yang digunakan sebagai acuan penilaian berbeda-beda antara satu guru degan guru yang lainnya. Penilaian ranah pengetahuan disesuaikan dengan tuntutan KD mata pelajaran. Penilaian ranah keterampilan dilakukan secara bervariasi. 1) Pelaku penilaian. Pelaksanaan peniaian hasil belajar siswa dilakukan oleh teman sejawat dan guru. Penilaian oleh teman sejawat dilakukan untuk penilaian sikap, baik sikap spiritual maupun sosial. Penilaian oleh guru dilakukan untuk penilaian sikap, pengetahuan, dan keterampilan. 2) Jenis alat penilaian. Jenis penilaian yang digunakan adalah penilaian dengan tes dan nontes. Penilaian dengan tes dilakukan untuk penilaian ranah pengetahuan, sedangkan penilaian dengan nontes dilakukan untuk penilaian ranah sikap dan keterampilan. 3) Bentuk tes. Bentuk tes yang digunakan dalam penilaian hasil belajar adalah tes pilihan ganda, isian singkat, dan uraian (esai). Tes pilihan ganda digunakan untuk ulangan tengah semester (UTS) dan ulangan akshir semester (UAS). Tes isian singkat dan uraian digunakan untuk pemberian kuis atau ulangan harian.

2) Bentuk nontes

Bentuk nontes yang digunakan dalam penilaian hasil belajar siswa adalah pengamatan dan penilaian produk. Pengamatan digunakan untuk penilaian sikap dalam pebelajaran dan presentasi tugas-tugas. Penilaian produk digunakan untuk menilai produk pembelajaran yang ditugaskan guru. Penilaian melalui pengamatan dan penilaian produk dilakukan dengan rubrik pengamatan atau rubrik penilaian produk yang dibuat oleh guru.
3) Bentuk pelaporan hasil belajar

Hasil belajar siswa dilaporkan pada setiap akhir semester dalam bentuk laporan hasil belajar siswa (raport). Dalam raport, hasil belajar siswa dilaporkan dalam bentuk angka, huruf, predikat, dan deskripsi. Pelaporan nilai sikap dilakukan dengan menggunakan modus dan kecenderungan perubahan sikap yang terjadi selama proses pembelajaran. Pelaporan nilai pengentahuan dan keterampilan dilakukan dengan menggunakan ratarata pencapaian kompetensi. Nilai tersebut dibuatkan rentangan dan dari rentangan tersebut diberikan niai dalam bentuk huruf dan predikat. Deskripsi penilaian hasil belajar digunakan untuk menginformasikan pencapaian kompetensi siswa dalam setiap mata pelajaran sesuai dengan KD-nya.

4) Skala penilaian

Skala penilaian yang digunakan adalah skala 100 dan skala empat. Skala 100 digunakan untuk skor mentah setiap aspek penilaian, kecuali penilaian sikap. Skala empat digunakan untuk pelaporan hasil belajar kepada orang tua/wali murid. Konvensi nilai dari skala 100 ke skala empat serta pemberian nilai dalam bentuk huruf dan predikat dilakukan dengan rumus yang sudah ditentukan oleh sekolah.

5) Waktu penilaian

Waktu penilaian hasil belajar siswa dilakukan sesuai dengan aspek penilaian yang dinilai dan pelakunya. Penilaian sikap oleh guru dilakukan setiap proses pembelajaran dengan memperhatikan tindakan-tindakan ekstrim yang dilakukan oleh siswa selama pembelajaran berlangsung. Penilaian sikap oleh teman sejawat dilakukan sekali dalam satu semester. Penilaian 
pengetahuan dilakukan setiap penyelesaian KD untuk ulangan harian/kuis, setiap tengah semester, dan setiap akhir semester. Penilaian keterampilan dan penilaian produk dilakukan sesuai dengan kegiatan pembelajaran yang relevan. Penilaian produk dilakukan sekali dalam satu semester.

6) Teknik pengumpulan hasil belajar Teknik pengumpulan hasil belajar dilakukan melalui pengamatan partisipasi dalam pembelajaran, melalui pelaksanaan tes tertulis, melalui penilaian produk dan portofolio.

\section{Masalah-masalah dalam Penilaian Hasil Belajar}

Masalah-masalah yang dihadapi guru dalam penilaian hasil belajar siswa adalah 1) jumlah penialian, 2) kompleksitas penilaian, 3) pembuatan instrumen penilaian, 4) pelaksanaan penilaian, dan 5) pelaporan hasil belajar. 1) Jumlah unsur penilaian Jumlah komponen hasil belajar yang harus dinilai dalam pembelajaran merupakan salah satu masalah yang dihadapi guru. Pada saat pembelajaran sebelumnya, guru hanya terfokus untuk menilai kemampuan siswa menguasai materi pelajaran yang di dalamnya terintegrasi penilaian sikap dan keterampilan. Dengah tuntutan penilaian sikap dan keterampilan secara terpisah, guru merasa jumlah aspek hasil belajar yang harus dinilai bertambah dan hal tersebut berpengaruh terhadap waktu yang dimiliki untuk mempersiapkan pelajaran. Selain itu, untuk di tingkat SD penilaian hasil belajar dilakukan berdasarkan jumlah tema dan subtema yang ada.

\section{2) Kompleksitas aspek penilaian}

Kompleksitas penilaian hasil belajar muncul dari struktur kurikulum yang terdiri atas $\mathrm{KI}$ dan KD. Dalam hal ini, KD mata pelajaran terdiri atas $\mathrm{KD} \mathrm{KI}-1, \mathrm{KD}$ $\mathrm{KI}-2$, KD KI-3, dan KD KI-4. Tiap-tiap rumusan $\mathrm{KD}$ mata pelajaran dikaitkan dengan ranah hasil belajar yang menjadi sasaran pembelajaran. Oleh karena itu, tiap-tiap KD mata pelajaran terdiri atas penilaian sikap, pengetahuan, dan keterampilan. Dengan demikian, penilain hasil belajar siswa menjadi kompleks. Selain kompleksitas yang disebabkan oleh struktur kurikulum, kompleksitas juga muncul dari pelaku penilaian yang dilibatkan dalam penilaian hasil belajar. Dalam hal ini, pelaku penilaian yang dikehendaki untuk dilibatkan adalah guru, diri sendiri, dan teman sejawat.

3) Pembuatan instrumen penilaian

Walaupun sudah mendapat pelatihan pembuatan instrumen penilaian hasil belajar, guru ternyata masih mengalami kesulitan dalam membuat instrumen penilaian, khususnya untuk penilaian sikap dan keterampilan. Pada penilaian sikap, terutama sikap spiritual (KD KI-1) yang dihubungkan dengan materi pelajaran terkadang tidak jelas, baik yang hendak dicapai, cara mencapai maupun cara penilaian pencapaiannya termasuk rubriknya.

4) Pelaksanaan penilaian

Sehubungan dengan jumlah komponen penilaian yang banyak (KD KI-1 sampai dengan KD KI-4), pada praktiknya penilain belum bisa dilakukan seperti yang diharapkan oleh kurikulum. Misalnya, penilian sikap oleh teman sejawat, baru dilakukan oleh teman sebangku dan hanya dilaksanakan sekali dalam satu semester. Penilaian sikap oleh guru dilakukan secara umum, hanya 
dengan menilai komponen-komponen yang muncul secara ekstrim.

5) Pelaporan hasil belajar

Walaupun sudah dibuatkan perumusannya, pelaporan hasil belajar juga masih menjadi masalah. Masalahnya adalah dalam pembuatan deskripsi pencapaian kompetensi. Deskripsi pencapaian kompetensi yang dibuat dalam laporan hasil belajar, cenderung, mirip satu sama lain, sehingga tidak dapat dilihat dengan jelas perbedaan kemampuan yang dimiliki oleh siswa yang satu dengan yang lainnya. Selain itu, pelaporan hasil belajar untuk tingkat SD hanya berisi deskripsi pencapaian kompetensi siswa sesuai mapel, sementara, pembelajaran dilakukan secara terintegrasi.

Profil pelaksanaan penilaian hasil belajar dan masalah-masalah yang dihapi guru dalam penilaian hasil belajar siswa adalah dua hal yang tidak dapat dipisahkan. Oleh karena itu, pebahasan temuan hasil penelitian ini diuraikan sesuai dengan unsur-unsur penilaian yang dipaparkan dalam profil penilaian hasil belajar siswa yang meliputi: ranah/domain penilaian, pelaku penilaian, jenis alat penilaian, bentuk tes, bentuk nontes, bentuk pelaporan hasil belajar, skala penilaian, waktu penilaian, dan teknik pengumpulan hasil belajar.

Berdasarkan temuan hasil penelitian ini, dapat dinyatakan bahwa ranah penilaian yang digunakan oleh guru dalam penilaian hasil belajar siswa sudah sesuai dengan tuntutan Kurikulum 2013 dengan melibatkan ranah sikap, pengetahuan, dan keterampilan (Permendikbud No. 67/2013). Namun demikian, terdapat sejumlah permasalahan terkait dengan pengembangan instrumen penilaian yang digunakan, pelaku penilaian, dan waktu pelaksanaan penilaian.

Sesuai dengan tuntutan kurikulum, pengembangan kompetensi sikap, baik sikap spritual maupun sikap sosial, dikaitkan langsung dengan pengembangan kompetensi pengetahuan (KD KI-3). Oleh karena itu, instrumen peniaian sikap dikembangkan sesuai dengan materi pokok yang diajarkan. Contoh pada mata pelajaran IPA di kelas IV SD dengan tema "CitaCitaku" dan subtema "Hebatnya Citacitaku" ditemukan pernyataan KI, KD, dan indikator penilaian sikap spiritual dan sosial sebagai berikut.

KI-1: Menerima, menjalankan, dan menghargai ajaran agama yang dianutnya.KD $\mathrm{KI}-1$ : Bertambah keimanannya dengan menyadari hubungan keteraturan dan kompleksitas alam dan jagat raya terhadap kebesaran Tuhan yang menciptakannya, serta mewujudkan dalam pengamalan ajaran agama yang dianutya.Indikator instrumen penilaian sikap spiritual (KD $\mathrm{KI}$-1) meliputi, ketaatan dalam beribaah, berdoa sebelum dan sesudah kegiatan, toleransi dalam beribadah, dan perilaku syukur.

KI-2: Menunjukkan perilaku jujur, disiplin, tanggung jawab, santun, peduli, dan percaya diri dalam berinteraksi dengan keluarga, teman, guru, dan tetangganya. KD KI-2: Menunjukkan perilaku ilmiah (memiliki rasa ingin tahu, objektif, jujur, teliti, cermat, tekun, hatihati, tanggung jawab, terbuka, dan peduli lingkungan) dalam aktivitas sehari-hari sebagai wujud implementasi sikap dalam melakukan inkuiri ilmiah dan berdiskusi. Indikator instrumen penilaian sikap sosial (KD KI-2) meliputi: disiplin, jujur, 
tanggung jawab, dan teliti. (Wimba, 2015).

Berdasarkan penyataan $\mathrm{KI}$ dan $\mathrm{KD}$ di atas, terlihat bahwa inikator instrumen yang digunakan untuk penilaian sikap spiritual tidak dikaitkan dengan pernyataan KD untuk materi pelajaran IPA (KD KI-1), tetapi dibuat secara umum sesuai dengan pernyataan KI. Inikator instrumen penilaian sikap sosial mencerminkan sebagian isi KD KI-2 yang juga bersifat umum. Dengan cara tersebut instrumen penilaian sikap spirtual dan sosial menjadi sama untuk seluruh mata pelajaran. Hal tersebut akan memudahkan penilaian sikap, namun belum mencerminkan pengembangan penilaian sikap spiritual dan sosial yang terkait dengan materi pelajaran.

Berdasarkan hasil wawanca dengan guru-guru, dapat dinyatakan bahwa pelaku penilaian yang dilibatkan dalam penilaian sikap spiritual dan sosial adalah guru dan teman sejewat secara terbatas. Guru melakukan penilaian sikap spiritual dan sosial dengan memerhatikan sikap-sikap ekstrim siswa. Selama proses penilaian, nilai sikap spiritual dan sosial yang diperoleh siswa ada dalam kategori baik sampai dengan sangat baik. Cara penilaian yang dilakukan oleh guru, kiranya, sudah tepat karena hanya perubahan-perubahan sikap yang eksrtimlah yang harus diperhatikan, terutama yang dinilai masih kurang dan perlu untuk ditingkatkan. Penilaian oleh teman sejawat yang baru dilakukan adalah penilaian oleh teman sebangku dan dilaksanakan sekali dalam satu semester. Permasalahan tersebut, ternyata, berkaitan dengan masalah penggandaan instrumen dan kredibilitas data yang diperoleh. Apabila penilaian ini dilakukan setiap akhir pelajaran, maka akan diperlukan penggandaan instrumen yang banyak dan berkonsekuensi dengan biaya penggandaan dan waktu yang diperlukan untuk penabulasian data. Pelaksanaan penilaian oleh teman sejawat hanya dilakukan oleh teman sebangku dengan alasan bahwa mereka yang duduk sebangkulah yang saling mengetahui dengan baik perkembangan sikap temannya.

Dengan mempertimbangkan kompleksitas penilaian sikap, baik sikap spirtual maupun sosial yang dialami guru di lapangan, penilaian sikap hendaknya dapat dirumuskan kembali dengan merenungkan tujuan dan sasaran pembelajaran pengembangan sikap. Perubahan sikap merupakan pengaruh iringan dari keseluruahn pembelajaran. Oleh karena itu, penilaian sikap cukup dilakukan secara umum saja. Untuk menyederhanakan penilaian sikap direkomendasikan agar penilaian sikap spiritual dilakukan oleh guru dan siswa sendiri, sedangkan penilaian sikap sosial dilakukan oleh guru, teman sejawat, dan orang tua/wali. Penilaian sikap (spritual dan sosial) oleh guru difokuskan pada perkembangan sikap yang bersifat ekstrim sehingga segera dapat ditindaklanjuti dalam proses pembelajaran. Penilain sikap spritual oleh siswa sendiri dapat dilihat sebagai pelaksanaan penilaian diri (selfassessment) yang mengarah pada pembangunan karekter pribadi siswa. Penilain sikap sosial oleh teman sejawat dapat dilihat sebagai bentuk penilaian sikap sosial yang harus dikembangkan sebagai makhluk sosial. Penilaian oleh orang tua/wali dapat dilihat sebagai kontribusi orang tua/wali alam perkembangan pendidikan anak- 
anaknya. Dengan cara tersebut, penilaian hasil belajar siswa apat dilakukan secara komprehensif dengan melibatkan atasan, diri sendiri, teman sejawat, dan keluarga (Subagia \& Wiratma, 2012).

Waktu pelaksanaa penilaian oleh guru dapat dilakukan setiap pembelajaran, sedangkan oleh diri sendiri, teman sejawat, dan orang tua/wali dapat dilakukan secara periodik, misalnya satu kali atau dua kali dalam satu semester bersamaan dengan pelaksanaan ulangan tengah semester dan ulangan akhir semester. Penilaian sikap spirutal dan sosial sebaiknya bersipat umum, dalam arti tidak dikaitkan dengan materi pelajaran. Dengan demikian, guru tidak akan susah mengembangkan instrumen penilaian dan melaksanakan penilaian.

Jenis penilaian yang dilakukan oleh guru sudah sesuai dengan tuntutan kurikulum, yaitu dengan melibatkan penilaian melalui tes dan nontes. Bentuk tes yang digunakan selama ini adalah tes uraian untuk kuis dan ulangan harian, dan tes pilihan ganda untuk ulangan tengah semester dan akhir semester.Bentuk nontes yang digunakan terbatas pada pengamatan, penilaian teman sejawat, dan penilaian produk. Apabila dimungkinkan, maka penggunaan tes pilihan ganda perlu dikurangi karena kurang mencerminkan kompetensi. Bentuk nontes yang juga perlu dipertimbangkan adalah wawancara. Hal tersebut dapat digunakan untuk mengetahui kemampuan real siswa.

Bentuk pelaporan hasil belajar (raport) ada variasi yang mencolok antara tingkat SD, SMP, dan SMA. Di tingkat SD, laporan hasil belajar anak hanya dituliskan berdasarkan KI. Untuk aspek sikap, deskripsi pencapaian hasil belajar siswa digambarkan menjadi satu kesatuan untuk KD KI-1 dan KD KI-2 tanpa disertai dengan deskripsi hasil belajar tiap-tiap mata pelajaran (mapel). Untuk aspek pengetahuan dan keterampilan, deskripsi pencapaian hasil belajar siswa digambarkan untuk KD KI3 dan KD KI-4 dan disertai dengan deskripsi pencapaian hasil belajar tiaptiap mapel. Dalam deskripsi pencapaian hasil belajar dituliskan capaian positif siswa dan hal-hal yang perlu ditingkatkan. Berikut ini adalah cuplikan beberapa deskripsi laporan hasil belajar siswa SD kelas IV.

$\mathrm{KI}-1$ : Sangat terbiasa alam melaksanakan Tri Sandya dan beribadah tepat waktu, khusus dalam berdoa dan berperilaku bersyukur.KI-2: Sangat baik dalam perilaku santun, jujur, disiplin, tanggung jawab, percaya diri, dan cinta tanah air.KI-3: Sangat baik dalam hal menggali informasi dari teks wawancara tentang jenis-jenis usaha dan pekerjaan serta kegiatan ekonomi dan koperasi. Masih perlu ditingkatkan dalam hal menggali informasi dari teks laporan hasil pengamatan tentang gaya, gerak, energi panas, bunyi, dan cahaya (mapel Bahasa Indonesia).KI-4: Sangat baik dalam hal menyajikan teks cerita petualangan tentang lingkungan dan sumber daya alam secara mandiri dalam teks bahasa indonesia juga alam hal mengolah dan menyajikan teks ulasan buku tentang nilai peninggalan sejarah dan perkembangan Hindu - Budha di Indonesia secara mandiri dalam bahasa Indonesia (mapel Bahasa Indonesia).(Dipetik dari Laporan Hasil Belajar Peserta Didik Kelas IV SD Negeri 1 Banjar Jawa, 2015) 
Untuk tingkat SMP dan SMA, laporan hasil belajar siswa dituliskan hampir sama dalam bentuk angka, huruf, dan deskripsi pencapaian kompetensi. Di tingkat SMP, hasil Belajar aspek pengetahuan (KI-3) dan keterampilan (KI-4) dieskripsikan dalam bentuk angka (skala 4) dan dalam beruk hurup (A - D), tanpa predikat. Hasil belajar $\mathrm{KI}-1$ dan $\mathrm{KI}$ 2 dituliskan dalam bentuk huruf dalam satu mapel yang menyatakan kategori kompetensi sebagai berikut: Sangat Baik (SB), Baik (B), Cukup (C), dan Kurang (K) dan dalam bentuk deskripsi antarmapel. Selain itu, pencapaian hasil belajar untuk kompetensi pengetahuan, keterampian, dan sikap spiritual dan sosial diberikan alam bentuk deskripsi catatan. Berikut ini adalah contoh bentuk catatan yang diberikan guru dalam laporan hasil belajar siswa SMP kelas VIII.

Mata pelajaran Matematika: Pengetahuan, penguasaan semua KD sudah sangat baik, tetapi masih perlu ditingkatkan pada penerapan persamaan kuadrat an geometri; Keterampilan, suah sangat baik dalam hal membuat model matematika dengan konsep aljabar dan melukis unsur-unsur bangun datar; Sikap Sosial dan Spiritual, sikap disiplin, kejujuran, dan tanggung jawab selama kegiatan pembelajaran sudah baik masih perlu ditingkatkan.

Mata pelajaran IPA: Pengetahuan, penguasaan kompetensi baik, khususnya dalam menjelaskan struktur dan fungsi sistem ekskresi pada manusia dan masih perlu peningkatan dalam hal memahami tekanan zat cair dan penerapannya sehari-hari; Keterampilan, sudah sangat baik dalam mengerjakan tugas, khususnya portofolio, proyek, dan dalam praktikum; Sikap Sosial dan
Spiritual, sangat baik dalam mengikuti pelajaran khususnya dalam hal kejujuran, kedisiplinan, dan sikap tanggung jawab.

Mata pelajaran IPS: Pengetahuan, penguasaan kompetensi baik khususnya dalam tema peran dan fungsi interaksi sosial masih perlu ditingkatkan pemahaman materi kemerdekaan sebagai modal dasar pembangunan; Keterampilan, kemampuan mengerjakan semua tugas yang ditargetkan sangat baik namun keterampilan pengamatan dan strategi pemecahan masalah perlu ditingkatkan; Sikap Sosial dan Spiritual, sikap dalam mengikuti pelajaran sudah baik, khususnya dalam hal kejujuran, kedisiplinan, tanggung jawab, percaya diri ditingkatkan. (Dipetik dari Laporan Hasil Belajar Peserta Didik Kelas VIII SMP Negeri 1 Singaraja, 2015)

Untuk tingkat SMA, pencapaian kompetensi pengetahuan (KI-3) dan keterampilan (KI-4) dinyatakan masingmasing dalam bentuk angka (skala 4) dan huruf $(A-D)$ yang menyatakan predikat. Pencapaian kompetensi sikap spiritual dan sosial (KI-1 an KI-2) dituliskan dengan cara yang sama dengan yang dilakukan untuk tingkat SMP. Sama halnya dengan tingkat SMP, di tingkat SMA deskripsi pencapaian kompetensi aspek pengetahuan, keterampilan, dan sikap spiritual dan sosial juga dituliskan dalam bentuk catatan. Berikut ini adalah contoh bentuk catatan yang diberikan guru dalam laporan hasil belajar siswa SMA.

Mata pelajaran matematika IPA: Pengetahuan: menguasai komeptensi dengan baik; Keterampilan, menguasai kompetensi dengan baik; Sikap Spiritual dan Sosial: menunjukkan sikap disiplin, sopan, dan jujur. 
Mata pelajaran biologi: Pengetahuan, semua kompetensi tuntas; Keterampilan, menguasai seluruh kompetensi dengan kualitas melebihi yang diharapkan; Spiritual dan Sosial, semua kompetensi sikap sangat baik.

Mata pelajaran fisika: Pengetahuan, baik, seluruh kompetensi sudah dipahami; Keterampilan,sudah terampil dalam kegiatan praktik. Kembangkan sikap ilmiah; Sikap Spiritual dan Sosial, sudah konsisten menunjukkan sikap beriman, bertaqwa, jujur, dan kontrol diri. Mata pelajaran kimia: Pengetahuan, sudah memahami kompetensi dasar kelarutan, koloid, dan tingkatkan pemahaman materi perhitungan $\mathrm{pH}$ asam basa; Keterampilan, sudah terampil mengomunikasikan materi dan menggunakan alat-alat laboratorium pada praktikum penentuan $\mathrm{pH}$ larutan asam basa dan kadar zat dengan metoe titrasi; Sikap Spiritual dan Sosial, sudah konsisten menunjukkan sikap beriman, bertaqwa, jujur, dan konsistensi diri.

Berdasarkan uraian di atas, dapat dinyatakan bahwa laporan hasil belajar siswa bervariasi sangat mencolok, terutama untuk tingkat SD. Dengan membaca laporan tersebut, sulit diketahui kemampuan relatif siswa terhadap siswa lainnya karena tidak ada angka pembanding dengan skala tertentu. Untuk tingkat SMP dan SMA, angka yang dituliskan tidak serta merta dapat dipahami oleh orang tua/wali murid karena laporan hasil belajar dibuat alam skala empat dengan interval 0,32-0,33. Pada masa lalu, angka yang digunakan untuk melaporkan hasil belajar siswa adalah angka dalam skala 11 atau 100 . Angka-angka tersebut mudah untuk dipahami oleh para orang tua/wali murid.
Misalnya, apabila anak mendapat nilai 8 atau 80, maka dapat dipahami bahwa kemampuan anak untuk mata pelajaran tersebut baru mencapai $80 \%$. Jadi, kalau belum puas dengan capaian tersebut mereka akan mendorong anak-anaknya untuk belajar lebih giat untuk pelajaran tersebut. Deskripsi laporan hasil belajar yang ditulikan saat ini, tidak dapat secara langsung mendorong orang tua/wali untuk ikut berpartisipasi dalam menyukseskan pendidikan anakanaknya karena kemampuan relatif anak-anaknya tidak terlihat.

\section{SIMPULAN DAN SARAN}

Profil penilaian hasil belajar siswa berdasarkan Kurikulum 2013 menunjukkan bahwa terdapat keberagaman penilaian hasil belajar dan pelaporan hasil belajar siswa antar jenjang penidikkan dan antar mapel (mata pelajaran). Secara umum, dapat digambarkan bahwa profil penilaian hasil belajar siswa telah menggabarkan tuntutan kurikulum, antara lain: pelibatan ranah pembelajaran yang meliputi aspek sikap, pengetahuan, dan keterampilan; penggunaan jenis penilaian berupa tes dan nontes, penggunaan teknik penilaian melalui pengamatan, tes, dan penilaian produk dan portofolio. Penggunaan tes uraian untuk kuis dan ulangan harian, dan penggunaan tes pilihan ganda untuk ulangan tengah semester dan akhir semester. Namun demikian, ada sejumlah komponen pendukung peniaian yang belum tergambarkan secara memadai. Komponen-komponen pendukung tersebut, antara lain: pembuatan instrumen penilaian sikap, baik untuk sikap spritual maupun sosial; pembuatan instrumen penilain tugastugas dan pelaksanaan peniaian tugas 
belum optimal; pelaksanaan penilaian diri sendiri dan penilaian teman sejawat belum berjalan optimal.

Laporan hasil belajar siswa (raport) dideskripsikan alam bentuk angka, huruf, predikat, dan deskripsi kompetensi untuk tiap-tiap mata pelajaran, kecuali di tingkat SD yang laporan hasil belajar siswanya hanya dituliskan dalam bentuk deskripsi saja untuk tiap-tiap aspek kompetensi (sikap, pengetahuan, dan keterampilan). Oleh karena itu, para orang tua/wali mengalami kesulitan dalam memahami isi laporan hasil belajar siswa tersebut. Akibatnya, mereka tidak dapat berpartisipasi aktif dalam meningkatkan mutu pendidikan anak-anaknya.

Berdasarkan temuan tersebut, disarankan kepada seluruh pemangku kepentingan pendidikan, baik yang ada di tingkat kabupaten, provinsi, maupun nasional agar melakukan harmonisasi penilaian hasil belajar dan pelaporan hasil belajar siswa. Penilaian hasil belajar siswa hendaknya mudah dirancang dan dilaksanaan serta tetap mengetengahkan prinsip-prinsip penilaian, seperti komprehensif, objektif, transparan, dan akuntabel. Salah satu unsur penilaian yang belum dilibatkan dalam penilaian hasil belajar siswa, terutama untuk penilaian sikap adalah penilaian oleh orang tua/wali karena perkembangan sikap siswa dapat dilihat dari kebiasaannya di rumah atau di lingkungan keluarga.

\section{DAFTAR PUSTAKA}

Arikunto, S. (1999). Dasar-dasar evaluasi pendidikan. Bumi Aksara.
Douglas, B. H. (2004). Language Assessment Principle and Classroom Practices. NY: Pearson Education.

Ekawarna, D. R. (2011). Penelitian Tindakan Kelas. Jambi: Gaung Persada.

Jihad, A. (2008). Evaluasi pembelajaran. Multi Pressindo.

Kunandar. (2007). Guru Profesional. Jakarta: PT Raja Grafinda.

Lynch, B. K. (1996). Language program evaluation: Theory and practice. Cambridge University Press.

Munadi, Y. (2008). Media Pembelajaran sebuah pendekatan baru. Jakarta: Gaung Persada Pers.

Nasution, S. (2000). Berbagai pendekatan dalam proses belajar dan mengajar. PT. Bina Aksara.

Subagia, I. W. (2013). Implementasi Pendekatan Ilmiah dalam Kurikulum 2013 untuk Mewujudnyatakan Tujuan Pendidikan Nasional. In Prosiding Seminar Nasional MIPA.

Subagia, I. W., \& Wiratma, I. G. L. (2012). Penilaian Kompetemsi Kepala Sekolah dan Guru dalam Bekerja di Sekolah. Jurnal Pendidikan Dan Pengajaran, 45(3).

Sugiyono, D. (2006). Statistika untuk penelitian. Bandung: CV. Alfabeta.

Supratiknya, A. (2012). Penilaian hasil belajar dengan teknik nontes. Yogyakarta: Universitas Sanata Dharma.

Suprijono, A. (2009). Cooperative Learning Teori dan Aplikasi PAIKEM. Yogyakarta: Pustaka Pelajar. 